\title{
Synthesis, Crystal Structure of Tetra-Nuclear Macrocyclic Zn (II) Complex and Its Application as Catalyst for Oxidation of Benzyl Alcohol
}

\author{
Li-Hua Wang ${ }^{1}$, Zi-Jian Wang ${ }^{2}$, Mei-Li Zhao ${ }^{1, *}$, Xi-Shi Tai $^{1}$, Jian Ouyang ${ }^{3}$, Yun-Fei Li ${ }^{3}$, \\ Wei Zhang ${ }^{3}$, Wen-Lei Jia ${ }^{3}$
}

${ }^{1}$ College of Chemistry and Chemical Engineering, Weifang University, Weifang 261061, P. R. China. ${ }^{2}$ Kohodo (Weifang Free Trade Zone) Hydrogen Technology Co., Ltd, Weifang 261031, P. R. China. ${ }^{3}$ Shenzhen Kohodo Hydrogen Energy Co., Ltd., Shenzhen 518109, P. R. China.

Received: $8^{\text {th }}$ May 2021; Revised: $6^{\text {th }}$ September 2021; Accepted: $6^{\text {th }}$ September 2021 Available online: $7^{\text {th }}$ September 2021; Published regularly: December 2021

\section{Abstract}

A new six coordinated tetra-nuclear macrocyclic $\mathrm{Zn}(\mathrm{II})$ complex, $\mathrm{ZnL}_{4}(\mathrm{Phen})_{2}$ (1) (HL= 3-bromo-2hydroxybenzaldehyde-pyridine-2-carbohydrazone, Phen = 1,10-phenanthroline) has been synthesized by the selfassembly of 3-bromo-2-hydroxybenzaldehyde-pyridine-2-carbohydrazone, $\mathrm{Zn}\left(\mathrm{CH}_{3} \mathrm{COO}\right)_{2} \cdot 2 \mathrm{H}_{2} \mathrm{O}, \mathrm{NaOH}$ and 1,10 phenanthroline in water/ethanol ( $\mathrm{v}: \mathrm{v}=1: 3)$ solution. Complex 1 was characterized by elemental analysis, infra red (IR), and single-crystal X-ray diffraction (XRD) analysis. The results show that Zn1 and Zn1b ions are sixcoordinated with a distorted octahedral geometric configuration by four $\mathrm{O}$ atoms of two different $\mathrm{L}$ ligands and two $\mathrm{N}$ atoms of two different $\mathrm{L}$ ligands, $\mathrm{Zn} 1 \mathrm{a}$ and $\mathrm{Zn} 1 \mathrm{c}$ ions are also six-coordinated with a distorted octahedral geometric configuration by two $\mathrm{N}$ atoms of two different $\mathrm{L}$ ligands, two $\mathrm{N}$ atoms of Phen ligands and two $\mathrm{O}$ atoms of two different L ligands. Complex (1) forms $3 \mathrm{D}$ network structure by the $\pi-\pi$ interaction. The selective oxidation reactions of benzyl alcohols catalyzed by complex (1) was investigated. The highest benzyl alcohol conversion and benzaldehyde selectivity were obtained at $100{ }^{\circ} \mathrm{C}$ for $4 \mathrm{~h}$ under 5 bar of $\mathrm{O}_{2}$.

Copyright (C 2021 by Authors, Published by BCREC Group. This is an open access article under the CC BY-SA License (https://creativecommons.org/licenses/by-sa/4.0).

Keywords: Hydrazone; Tetra-nuclear macrocyclic Zn(II) complex; Synthesis; Structural characterization; Oxidation of benzyl alcohol

How to Cite: L.-H. Wang, Z.-J. Wang, M.-L. Zhao, X.-S. Tai, J. Ouyang, Y.-F. Li, W. Zhang, W.-L. Jia (2021). Synthesis, Crystal Structure of Tetra-Nuclear Macrocyclic Zn(II) Complex and Its Application as Catalyst for Oxidation of Benzyl Alcohol. Bulletin of Chemical Reaction Engineering \& Catalysis, 16(4), 839-846 (doi:10.9767/bcrec.16.4.10978.839-846)

Permalink/DOI: https://doi.org/10.9767/bcrec.16.4.10978.839-846

\section{Introduction}

Macrocyclic metal complexes exhibit widespread potential applications in cytotoxicity, antioxidant and antibacterial activities [1-4], photoluminescent property [5-7], catalytic proper-

* Corresponding Author.

Email: sdzml@163.com (M.L. Zhao);

Telp: +86-536-8785283, Fax: +86-536-8785363 ties, such as: hydrosilylation of diphenyl acetylenes [8], electrocatalytic oxygen reduction $[9,10]$, ring opening reaction [11], electrocatalytic $\mathrm{CO}_{2}$ reduction [12], hydrogen evolution reaction [13], water oxidation catalysis [14], gas adsorption [15], magnetic property [16], and so on. According to the literatures report [17-22], precious metal oxide, hydrogen peroxide, precious metal nanomaterials and MOFs are used as a catalyst to produce benzaldehyde by oxidation of 
benzyl alcohol. However, there are few studies on catalytic oxidation of benzyl alcohol to benzaldehyde by macrocyclic metal complexes. In our previous works, some macrocyclic metal complexes have been synthesized and their structures and properties have also been investigated [23-28]. In order to further investigate the structure and property of macrocyclic metal complexes, in this work, a new tetra-nuclear macrocyclic $\mathrm{Zn}(\mathrm{II})$ complex, $\mathrm{ZnL}_{4}(\mathrm{Phen})_{2}$ (1) (HL = 3-bromo-2-hydroxybenzaldehydepyridine-2-carbohydrazone, Phen $=1,10$ phenanthroline) has been synthesized by the self-assembly of $3-\mathrm{bromo-2}$ hydroxybenzaldehyde-pyridine-2 carbohydrazone, $\mathrm{Zn}\left(\mathrm{CH}_{3} \mathrm{COO}\right)_{2} \cdot 2 \mathrm{H}_{2} \mathrm{O}, \mathrm{NaOH}$ and 1,10-phenanthroline in water/ethanol (v:v $=1: 3$ ) solution. The structure of complex (1) was characterized by elemental analysis, IR and single-crystal X-ray diffraction analysis. The selective oxidation reactions of benzyl alco- hols catalyzed by complex 1 was investigated. The highest benzyl alcohol conversion and benzaldehyde selectivity were obtained at $100{ }^{\circ} \mathrm{C}$ for $4 \mathrm{~h}$ under 5 bar of $\mathrm{O}_{2}$.

\section{Materials and Method}

\subsection{Materials and Measurements}

The ligand of 3-bromo-2hydroxybenzaldehyde-pyridine- 2 carbohydrazone was synthesized by our research group itself and confirmed by element analysis and infrared spectroscopy. Other reagents of $\mathrm{NaOH}$ (A. R.), 1,10-phenanthroline (A. R.), and $\mathrm{Zn}\left(\mathrm{CH}_{3} \mathrm{COO}\right)_{2} \cdot 2 \mathrm{H}_{2} \mathrm{O}$ (A. R.) were purchased from Sinopharm Chemical Reagent Co., Ltd.. Using an Elementar Vario III EL elemental analyzer (Hanau, Germany) to analyze $\mathrm{C}, \mathrm{H}$ and $\mathrm{N}$. The crystal data of $\mathrm{ZnL}_{4}(\mathrm{Phen})_{2}$ (1) were collected on a Bruker Smart CCD diffractometer (Bruker, Billerica, MA, USA). The se-

Table 1. Crystallographic data of tetra-nuclear macrocyclic Zn(II) complex (1).

\begin{tabular}{|c|c|}
\hline Empirical formula & $\mathrm{C}_{19} \mathrm{H}_{12} \mathrm{BrN}_{4} \mathrm{O}_{2} \mathrm{Zn}$ \\
\hline Formula weight & 473.61 \\
\hline Temperature/K & $100.00(10)$ \\
\hline Crystal system & Orthorhombic \\
\hline Space group & Fddd \\
\hline$a / \AA ̊$ & $18.8920(5)$ \\
\hline$b / \AA$ & $38.6707(10)$ \\
\hline$c / \AA$ & $26.7016(6)$ \\
\hline$\alpha /^{\circ}$ & 90 \\
\hline$\beta /^{\circ}$ & 90 \\
\hline$y /{ }^{\circ}$ & 90 \\
\hline Volume/ $/ \AA^{3}$ & 19507.3(8) \\
\hline$Z$ & 32 \\
\hline$\rho_{\text {calc }}, \mathrm{mg} / \mathrm{mm}^{3}$ & 1.290 \\
\hline$\mu / \mathrm{mm}^{-1}$ & 3.462 \\
\hline$S$ & 1.130 \\
\hline$F(000)$ & 7520 \\
\hline Index ranges & $\begin{array}{l}-23 \leq h \leq 13 \\
-47 \leq k \leq 35 \\
-22 \leq l \leq 32\end{array}$ \\
\hline Reflections collected & 11111 \\
\hline$\theta /^{\circ}$ & $3.253-73.313$ \\
\hline Independent reflections & $4816[R(\mathrm{int})=0.0261]$ \\
\hline Data/restraints/parameters & $4816 / 0 / 245$ \\
\hline Goodness-of-fit on $F^{2}$ & 1.130 \\
\hline Refinement method & Full-matrix least-squares on $F^{2}$ \\
\hline Final $R$ indexes [I $>=2 \sigma(I)]$ & $R_{1}=0.0555, w R_{2}=0.1247$ \\
\hline Final $R$ indexes [all data] & $R_{1}=0.0586, w R_{2}=0.1266$ \\
\hline Largest diff. peak/hole / e $\AA^{-3}$ & $0.78 /-0.51$ \\
\hline
\end{tabular}


lective oxidation reactions of benzyl alcohols catalyzed by complex 3 was carried out in a 20 $\mathrm{mL}$ stainless steel high pressure reactor. The conversion of benzyl alcohol and the selectivity of benzaldehyde were determined by gas chromatography spectrometer equipped with a SE54 column (GC-1100, Beijing Purkay General Instrument Co. Ltd).

\subsection{Synthesis of Tetra-nuclear Macrocyclic Zn(II) Complex}

3-Bromo-2-hydroxybenzaldehyde-pyridine-2carbohydrazone $(0.5 \mathrm{mmol}, 0.11601 \mathrm{~g})$ and $\mathrm{NaOH}(0.5 \mathrm{mmol}, 0.020 \mathrm{~g})$ were dissolved into $20 \mathrm{~mL}$ ethanol $/ \mathrm{H}_{2} \mathrm{O}$ solution ( $\mathrm{v}: \mathrm{v}=1: 1$ ) with stirring at room temperature. After $0.5 \mathrm{~h}$, $\mathrm{Zn}\left(\mathrm{CH}_{3} \mathrm{COO}\right)_{2} \cdot 2 \mathrm{H}_{2} \mathrm{O}(0.5 \mathrm{mmol}, 0.0865 \mathrm{~g})$ was added to the above solution. After reaction at ca. $75{ }^{\circ} \mathrm{C}$ for 3 hours, 1,10-phenanthroline (0.5 mmol, $0.0901 \mathrm{~g}$ ) was added to the above solution. The reaction mixture was stirred for $4 \mathrm{~h}$ at $c a .75{ }^{\circ} \mathrm{C}$. The white precipitate formed and filtered. Slowing volatilization of filtrate at room temperature, the crystals of tetra-nuclear macrocyclic $\mathrm{Zn}$ (II) complex (1) were obtained in 30 days. Elemental analysis (\%) calcd. for $\mathrm{C}_{19} \mathrm{H}_{12} \mathrm{BrN}_{4} \mathrm{O}_{2} \mathrm{Zn}: \mathrm{C}, 48.14 ; \mathrm{H}, 2.53 ; \mathrm{N}, 11.82$. Found (\%): C, 47.96; H, 2.76; N, 11.59 .

\subsection{Crystal Structure Determination}

A suitable $(0.12 \mathrm{~mm} \times 0.11 \mathrm{~mm} \times 0.09 \mathrm{~mm})$ single crystal of tetra-nuclear macrocyclic $\mathrm{Zn}$ (II) complex (1) was selected to collect data on a Super Nova, Dual, Cu at zero, AtlasS2 diffractometer. The crystal was kept at 100.00(10) $\mathrm{K}$ during data collection. SHELXL program [29] was used to solve the structure by direct

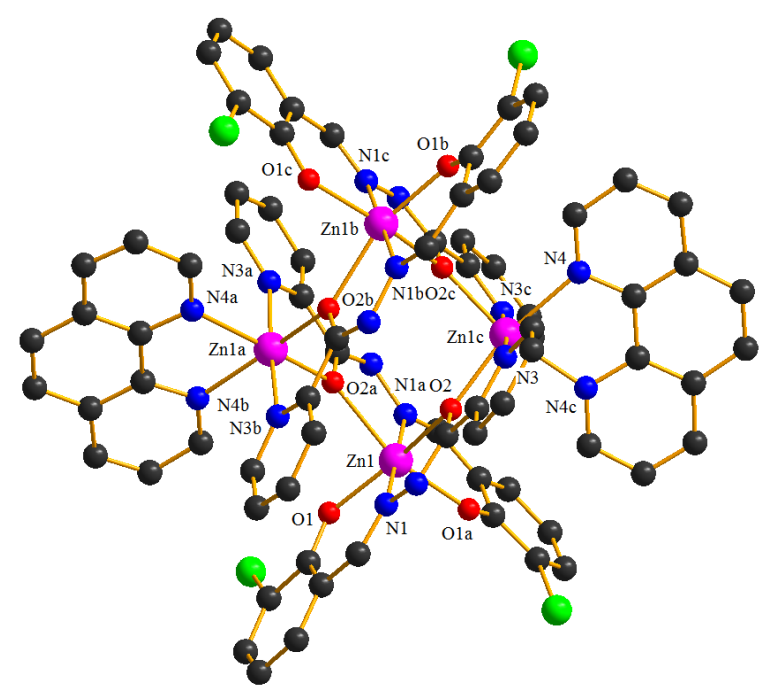

Figure 1. The molecular structure of tetranuclear macrocyclic Zn(II) complex (1). method, and refined by the OLEX2 program [30]. The crystallographic data of tetra-nuclear macrocyclic $\mathrm{Zn}(\mathrm{II})$ complex (1) are given in Table 1.

2.5 The Procedure for The Oxidation of Benzyl Alcohol

The selective oxidation reactions of benzyl alcohols catalyzed by tetra-nuclear macrocyclic $\mathrm{Zn}$ (II) complex (1) was carried out in a $20 \mathrm{~mL}$ stainless steel high pressure reactor. $0.050 \mathrm{~g}$ tetra-nuclear macrocyclic $\mathrm{Zn}$ (II) complex (1) catalyst, benzyl alcohol $(1.0 \mathrm{mmol})$ and 1,4 dioxane $(7 \mathrm{~mL})$ were added into the reactor, and then pure $\mathrm{O}_{2}$ was purged into the reactor. The suspension was stirred magnetically at 90 ${ }^{\circ} \mathrm{C}$ or $100{ }^{\circ} \mathrm{C}$ for $4 \mathrm{~h}$ under $3-5$ bar $\mathrm{O}_{2}$ pressure. The conversion of benzyl alcohol and the selectivity of benzaldehyde were determined by gas chromatography spectrometer equipped with a SE-54 column. The products were identified by comparison with known authentic standards, and an external standard method was used for the qualitative analysis.

\section{Results and Discussion}

3.1. Structural Description of Tetra-nuclear Macrocyclic Zn(II) Complex (1)

The structural analysis of tetra-nuclear macrocyclic Zn(II) complex (1) shows that it crystallizes in the orthorhombic system with the Fddd (no. 70) space group. The molecular structure of tetra-nuclear macrocyclic $\mathrm{Zn}$ (II) complex (1) is shown in Figure 1. The selected bond lengths $(\AA)$ and angles $\left(^{\circ}\right)$ for tetranuclear macrocyclic Zn(II) complex (1) are given in Table 2. As shown in Figure 1, the tetranuclear macrocyclic $\mathrm{Zn}$ (II) complex (1) is made up of four $\mathrm{Zn}(\mathrm{II})$ ions, four 3-bromo-2-

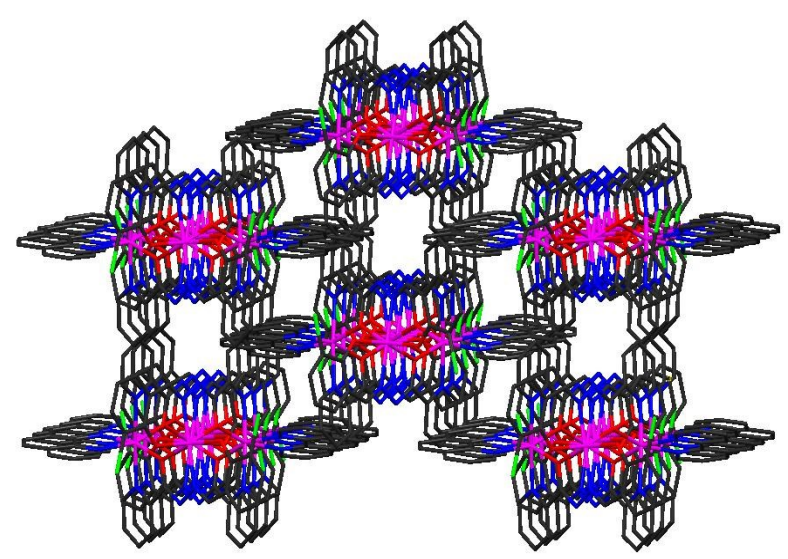

Figure 2. 3D network structure of tetra-nuclear macrocyclic $\mathrm{Zn}(\mathrm{II})$ complex (1). 
hydroxybenzaldehyde-pyridine - 2 carbohydrazone ligands and two 1,10phenanthroline ligands. In $\mathbf{1}$, four $\mathrm{Zn}(\mathrm{II})$ atoms adopt different coordination mode: $\mathrm{Zn} 1$ and $\mathrm{Zn} 1 \mathrm{~b}$ ions are six-coordinated with a distorted octahedral geometric configuration by four $\mathrm{O}$ atoms (Zn1: O1, O1a, O2, O2a; Zn1b: O1b, O1c, $\mathrm{O} 2 \mathrm{~b}, \mathrm{O} 2 \mathrm{c})$ of two different $\mathrm{L}$ ligands and two $\mathrm{N}$ atoms (Zn1: N1, N1a; Zn1b: N1b, N1c) of two different L ligands, Zn1a and Zn1c ions are also six-coordinated with a distorted octahedral geometric configuration by two $\mathrm{N}$ atoms (Zn1a: N3a, N3b; Zn1c: N3, N3c) of two different L ligands, two $\mathrm{N}$ atoms (Zn1a: N4a, N4b; Zn1c:
$\mathrm{N} 4, \mathrm{~N} 4 \mathrm{c}$ ) of Phen ligands and two $\mathrm{O}$ atoms (Zn1a: O2a, O2b; Zn1c: O2, O2c) of two different L ligands. Four $\mathrm{Zn}(\mathrm{II})$ atoms form tetranuclear macrocyclic structure by the bridge effect of four carbonyl oxygen atoms. The $\mathrm{Zn}-\mathrm{O}$ and $\mathrm{Zn}-\mathrm{N}$ distances are in the range of $2.046(3)-2.259(2) \AA(\mathrm{Zn}-\mathrm{O}), 2.052(3)-2.182(3) \AA$ (Zn-N), respectively, which are comparable to other $\mathrm{Zn}(\mathrm{II})$ complexes [31-33]. The tetranuclear macrocyclic $\mathrm{Zn}$ (II) complex (1) assemble an extended 3D supramolecular network structure via $\pi-\pi$ stacking interactions of aromatic rings of ligands (Figure 2).

Table 2. Selected bond lengths $(\AA ̊)$ and bond angles $\left(^{\circ}\right)$ for tetra-nuclear macrocyclic Zn(II) complex (1).

\begin{tabular}{|c|c|c|c|}
\hline Bond & $d$ & Angle & $\left({ }^{\circ}\right)$ \\
\hline Zn1-O1 & $2.046(3)$ & O1-Zn1-O1a & $100.83(17)$ \\
\hline Zn1-O1a & $2.046(3)$ & O1-Zn1-O2a & $90.26(10)$ \\
\hline $\mathrm{Zn} 1-\mathrm{O} 2$ & $2.259(2)$ & O2a-Zn1-O1a & 159.04(11) \\
\hline $\mathrm{Zn1-O2a}$ & $2.259(2)$ & O1a-Zn1-O2 & $90.26(10)$ \\
\hline Zn1-N1 & $2.052(3)$ & O1-Zn1-O2 & $159.04(11)$ \\
\hline Zn1-N1a & $2.052(3)$ & O1-Zn1-N1 & $87.57(12)$ \\
\hline $\mathrm{C} 6-\mathrm{Br} 1$ & $1.895(5)$ & O1a-Zn1-N1 & $93.15(12)$ \\
\hline $\mathrm{Zn} 1 \mathrm{c}-\mathrm{O} 2$ & $2.090(2)$ & O1-Zn1-N1a & $93.15(12)$ \\
\hline $\mathrm{Zn} 1 \mathrm{c}-\mathrm{O} 2 \mathrm{c}$ & $2.090(2)$ & O1a-Zn1-N1a & $87.57(12)$ \\
\hline Zn1c-N3 & $2.143(3)$ & O2-Zn1-O2a & $85.16(13)$ \\
\hline $\mathrm{Zn} 1 \mathrm{c}-\mathrm{N} 3 \mathrm{c}$ & $2.143(3)$ & N1a-Zn1-O2 & $105.14(11)$ \\
\hline Zn1c-N4 & $2.182(3)$ & O2a-Zn1-N1a & 73.99(11) \\
\hline $\mathrm{Zn} 1 \mathrm{c}-\mathrm{N} 4 \mathrm{c}$ & $2.182(3)$ & N1-Zn1-O2a & $105.14(11)$ \\
\hline C1-O1 & $1.293(5)$ & N1-Zn1-O2 & 73.99(11) \\
\hline $\mathrm{C} 8-\mathrm{O} 2$ & $1.288(4)$ & N1a-Zn1-N1 & $178.87(18)$ \\
\hline N1-N2 & $1.397(4)$ & $\mathrm{O} 2 \mathrm{c}-\mathrm{Zn} 2-\mathrm{O} 2$ & $99.56(14)$ \\
\hline $\mathrm{C} 7-\mathrm{N} 1$ & $1.297(5)$ & $\mathrm{O} 2 \mathrm{c}-\mathrm{Zn} 2-\mathrm{N} 3$ & $99.57(11)$ \\
\hline \multirow[t]{12}{*}{$\mathrm{C} 8-\mathrm{N} 2$} & $1.308(5)$ & $\mathrm{O} 2-\mathrm{Zn} 2-\mathrm{N} 3 \mathrm{c}$ & $99.57(11)$ \\
\hline & & O2-Zn2-N3 & $78.31(11)$ \\
\hline & & $\mathrm{O} 2 \mathrm{c}-\mathrm{Zn} 2-\mathrm{N} 3 \mathrm{c}$ & 78.31(11) \\
\hline & & $\mathrm{O} 2 \mathrm{c}-\mathrm{Zn} 2-\mathrm{N} 4 \mathrm{c}$ & $163.92(11)$ \\
\hline & & $\mathrm{O} 2-\mathrm{Zn} 2-\mathrm{N} 4 \mathrm{c}$ & $93.09(11)$ \\
\hline & & $\mathrm{O} 2 \mathrm{c}-\mathrm{Zn} 2-\mathrm{N} 4$ & $93.08(11)$ \\
\hline & & $\mathrm{O} 2-\mathrm{Zn} 2-\mathrm{N} 4$ & $163.92(11)$ \\
\hline & & N3c-Zn2-N3 & $176.77(17)$ \\
\hline & & N3-Zn2-N4 & $89.88(12)$ \\
\hline & & $\mathrm{N} 3 \mathrm{c}-\mathrm{Zn} 2-\mathrm{N} 4$ & $92.66(12)$ \\
\hline & & N3-Zn2-N4c & $92.66(12)$ \\
\hline & & N3c-Zn2-N4c & $89.88(12)$ \\
\hline
\end{tabular}

Symmetry transformations: a: 5/4-x, 5/4-y, $+z$; c: 5/4-x, $+y, 5 / 4-z$. 


\subsection{Activity of Benzyl Alcohol Oxidation}

After preparation and characterization of tetra-nuclear macrocyclic Zn(II) complex (1), its catalytic activity was investigated in the selective oxidation of benzyl alcohol with molecular oxygen as the sole oxidant. $\mathrm{O}_{2}$ is inexpensive and only produces water as its byproduct. The reaction temperature and pressure were optimized in the selective oxidation of benzyl alcohol in the presence of tetra-nuclear macrocyclic $\mathrm{Zn}$ (II) complex (1). The results are summarized in Table 3. A blank experiment showed a low benzyl alcohol conversion $(9.6 \%)$ at $100{ }^{\circ} \mathrm{C}$ under 5 bar of $\mathrm{O} 2$ with 1,4-dioxane as solvent for 4 h. By contrast, good benzyl alcohol conversions were observed tetra-nuclear macrocyclic $\mathrm{Zn}$ (II) complex (1), suggesting that complex (1) could catalyse the oxidation of benzyl alcohol. For tetra-nuclear macrocyclic $\mathrm{Zn}$ (II) complex (1), the benzyl alcohol conversion and benzaldehyde selectivity were $37.1 \%$ and $5.2 \%$ at $90{ }^{\circ} \mathrm{C}$ for $4 \mathrm{~h}$ under 5 bar $\mathrm{O}_{2}$. When the reaction temperature increase to $100{ }^{\circ} \mathrm{C}$, the benzyl alcohol conversion and benzaldehyde selectivity greatly enhanced to $78.1 \%$ and $29.2 \%$. The conversion of benzyl alcohol and selectivity of benzaldehyde were $49.0 \%$ and $10.8 \%$ at $100{ }^{\circ} \mathrm{C}$ for $4 \mathrm{~h}$ under 3 bar $\mathrm{O}_{2}$. The observed main by-product is benzoic acid, together with amounts of benzyl benzoate. The selectivities of benzoic acid are 55.3\%, $45.4 \%, 47.3 \%$ for complex (1) on oxidation reactions under $90{ }^{\circ} \mathrm{C} 5$ bar, $100{ }^{\circ} \mathrm{C} 5$ bar, and 100 ${ }^{\circ} \mathrm{C} 3$ bar, respectively. The highest benzyl alcohol conversion (78.1\%) and benzaldehyde selectivity $(29.2 \%)$ were obtained at $100{ }^{\circ} \mathrm{C}$ for $4 \mathrm{~h}$ under 5 bar of $\mathrm{O}_{2}$. Nabae et al. found that HBPI (hyperbranched polyimide) functionalized with TEMPO (2,2,6,6-tetramethylpiperidine-1-oxyl) could works as a heterogenous catalyst for the benzyl alcohol oxidation in the presence of a catalytic amount of $\mathrm{HNO}_{3}$ [34].

The benzyl alcohol conversion and benzaldehyde selectivity are $11 \%$ and $100 \%$ on TEMPO/HBPI, respectively [34]. Li et al [35]. reported that conjugated metalloporphyrin polymers (MnP-AMPs) with BET surface area of $345 \mathrm{~m}^{2} / \mathrm{g}$ had good catalytic performance for the oxidation of benzyl alcohol, achieving complete conversion within $2 \mathrm{~h}$ and benzaldehyde selectivity of 98\%. Asgharnejad et al. [36] synthesized three-dimensional copper-based coordination polymers [Cu(1,4-BDC$\left.\mathrm{Br})(\mathrm{DABCO})_{0.5}\right] \cdot \mathrm{xDMF} \cdot \mathrm{yH}_{2} \mathrm{O}$ using $\mathrm{Cu}\left(\mathrm{NO}_{3}\right)_{2} \cdot 3 \mathrm{H}_{2} \mathrm{O}$, triethylenediamine (DABCO), 2 -bromoterephthalate (1,4-BDC-Br), $\mathrm{CH}_{3} \mathrm{COOH}$, and DMF. The copper-based coordination polymers exhibited good activity (conversion: $38 \%$ ) and selectivity to benzaldehyde $(78 \%)$ in the benzyl alcohol oxidation using tert-butyl hydroperoxide as an oxidant in $\mathrm{DMF}$ at $40{ }^{\circ} \mathrm{C}$ for $4 \mathrm{~h}$ [36]. Based on the above results, the catalytic activity and selectivity of complex (1) in the oxidation of benzyl alcohol was lower than MnP-AMPs catalyst. Although the selectivity of benzaldehyde is less than those of TEMPO/HBPI and [Cu(1,4-BDC$\left.\mathrm{Br})(\mathrm{DABCO})_{0.5}\right] \mathrm{xDMF} \cdot \mathrm{yH}_{2} \mathrm{O}$, the complex (1) could oxidized benzyl alcohol with high activity using $\mathrm{O}_{2}$ as sole oxidant without adding any other substances.

To examine the scope of substrate of the oxidation reaction, we extended our studies to different combinations of alcohols. The results are

Table 3. Oxidation of benzyl alcohol to benzaldehyde on tetra-nuclear macrocyclic Zn(II) complex (1) in 1,4-dioxane.

\begin{tabular}{cccccccc}
\hline Entry & Catalysts & $\begin{array}{c}\text { Temperature } \\
\left({ }^{\circ} \mathrm{C}\right)\end{array}$ & $\begin{array}{c}\text { Pressure } \\
(\text { bar })\end{array}$ & $\begin{array}{c}\text { Reaction } \\
\text { time (h) }\end{array}$ & $\begin{array}{c}\text { Conversion } \\
(\%)\end{array}$ & $\begin{array}{c}\text { Benzylaldehyde } \\
\text { Selectivity (\%) }\end{array}$ & $\begin{array}{c}\text { Benzoic acid } \\
\text { Selectivity(\%) }\end{array}$ \\
\hline 1 & Complex (1) & 90 & 5 & 4 & 37.1 & 5.2 & 52.3 \\
2 & Complex (1) & 100 & 5 & 4 & 78.1 & 29.2 & 45.4 \\
3 & Complex (1) & 100 & 3 & 4 & 49 & 10.8 & 47.3 \\
\hline
\end{tabular}

Table 4. Catalytic activities of complex (1) for the oxidation of various alcohols.

\begin{tabular}{clccc}
\hline Entry & \multicolumn{1}{c}{ Substrates } & Conversion (\%) & Aldehyde Selectivity (\%) & Acid Selectivity (\%) \\
\hline 1 & 4-chlorobenzyl alcohol & 82.1 & 27.2 & 50.3 \\
2 & 4-methylbenzyl alcohol & 81.6 & 28.9 & 27.0 \\
3 & 4-methoxybenzyl alcohol & 86.4 & 7.7 & 60.7 \\
4 & n-butanol & 86.2 & 24.9 & 51.9 \\
\hline
\end{tabular}

Note: reaction condition: complex (1) $(0.05 \mathrm{~g}), 100^{\circ} \mathrm{C}, 5 \mathrm{bar}, 4 \mathrm{~h}$. 
summarized in Table 4. Aromatic alcohols including those bearing functional groups, such as: alkoxy, alkyl, and chloro, were able to undergo the corresponding oxidation reaction, and afforded good conversions of alcohols in the selective oxidation reaction. The conversions are $82.1 \%, 81.6 \%$, and $86.4 \%$ for 4 -chlorobenzyl alcohol, 4-methylbenzyl alcohol, and 4-methoxybenzyl alcohol, respectively. The nature of substituents (electron with drawing or electron-donating) has an ignore influence on the catalytic activity. Moreover, n-butanol also displayed a high catalytic activity with conversion of $86.2 \%$. The selectivities of aldehydes are $27.2 \%, \quad 28.9 \%, \quad 7.7 \%$, and $24.9 \%$ for 4-chlorobenzyl alcohol, 4-methylbenzyl alcohol, 4-methoxybenzyl alcohol, and n-butanol, respectively. It gives high selectivity of byproduct acids, and the selectivities of acids are $50.3 \%, \quad 27.0 \%, \quad 60.7 \%$, and $51.9 \%$ for 4-chlorobenzyl alcohol, 4-methylbenzyl alcohol, and 4-methoxybenzyl alcohol, respectively.

\section{Conclusions}

In summary, a new tetra-nuclear macrocyclic $\mathrm{Zn}$ (II) complex, $\mathrm{ZnL}_{4}(\mathrm{Phen})_{2}$ (1) has been synthesized and structural characterized by elemental analysis, IR, and single-crystal X-ray diffraction analysis. The selective oxidation reactions of benzyl alcohols catalyzed by complex (1) have been investigated.

\section{Acknowledgments}

This project was supported by National Natural Science Foundation of China (No. 21171132), Science Foundation of Weifang and Science Foundation of Weiyuan Scholars Innovation Team.

\section{References}

[1] Keypour, H., Rezaei, M.T., Jamshidi, M., Farida, S.H.M., Karamian, R. (2021). Synthesis, cytotoxicity, and antioxidant activity by in vitro and molecular docking studies of an asymmetrical diamine containing piperazine moiety and related $\mathrm{Zn}(\mathrm{II}), \mathrm{Cd}(\mathrm{II})$ and $\mathrm{Mn}(\mathrm{II})$ macrocyclic schif base complexes. Inorganic Chemistry Communications, 125, 108443. DOI: 10.1016/j.inoche.2021.108443

[2] Kou, H.Z., Wang, Y., Ding, P.P., Cheng, X.Z., Zhou, G.Q. (2020). Synthesis, crystal structure, phosphate hydrolysis activity and antibacterial activity of macrocyclic dinuclear Zn(II) complex with benzyl pendant-arms. Journal of Molecular Structure, 1216, 128299. DOI: 10.1016/j.molstruc.2020.128299
[3] Keypour, H., Mahmoudabadi, M., Shooshtari, A., Hosseinzadeh, L., Mohsenzadeh, F., Gable, R.W. (2017). Synthesis of $\mathrm{Mn}$ (II) and $\mathrm{Zn}$ (II) complexes with new macrocyclic Schiffbase ligands containing piperazine moiety: spectroscopic, structural, cytotoxic and antibacterial properties. Polyhedron, 127, 345354. DOI: 10.1016/j.poly.2017.02.008

[4] Tai, X.S., Meng, Q.G., Liu, L.L. (2016). Synthesis, crystal structure, and cytotoxic activity of a novel eight-coordinated dinuclear Ca(II)-Schiff base complex. Crystals, 6, 109. DOI: $10.3390 /$ cryst6090109

[5] Chang, F.F., Li, W.Q., Feng, F.D., Huang, W. (2019). Construction and photoluminescent properties of Schiff-base macrocyclic mono-/di-/trinuclear $\mathrm{Zn}^{\mathrm{II}}$ complexes with the common 2-ethylthiophene pendant arm. Inorganic Chemistry, 58, 7812-7821. DOI: 10.1021/acs.inorgchem.9b00454

[6] Chakraborty, T., Dasgupta, S., Bhattacharyya, A., Zangrando, E., Escudero, D., Das, D. (2019). A macrocyclic tetranuclear $\mathrm{Zn}^{\text {II }}$ complex as a receptor for selective dual fluorescence sensing of $\mathrm{F}^{-}$and $\mathrm{AcO}^{-}$: effect of a macrocyclic ligand. New Journal of Chemistry, 43, 13152-13161. D O : 10.1039/C9NJ03481A

[7] Zhang, K., Chen, T.T., Shen, Y.J., Zhang, L.F., Ma, S., Huang, Y. (2020). Luminescent macrocyclic Sm(III) complex probe for turnoff fluorescent and colorimetric water detection in organic solvents and liquid fuels. Sensors and Actuators B: Chemical, 311, 127887. DOI: $10.1016 /$ j.snb.2020.127887

[8] Yamamoto, K., Higuchi, K., Ogawa, M., Sogawa, H., Kuwata, S., Hayashi, Y., Kawauchi, S., Takata, T. (2019). Macrocyclic metal complexes bearing rigid polyaromatic ligands: synthesis and catalytic activity. ChemistryAn Asian Journal, 15, 356-359. DOI: 10.1002/asia.201901561

[9] Ni, Y.X., Lu, Y., Zhang, K., Chen, J. (2021). Aromaticity/antiaromaticity effect on activity of transition metal macrocyclic complexes towards electrocatalytic oxygen reduction. ChemSusChem, 14, 1835-1839. DOI: $10.1002 /$ cssc. 202100182

[10] Tammeveski, K., Zagal, J.H. (2018). Electrocatalytic oxygen reduction on transition metal macrocyclic complexes for anion exchange membrane fuel cell application. Current Opinion in Electrochemistry, 9, 207-213. DOI: 10.1016/j.coelec.2018.04.001 
[11] Tak, R.K., Kumar, M., Nazish, M., Menapara, T.K., Kureshy, R.I., Khan, N.U.H. (2018). Development of recyclable chiral macrocyclic metal complexes for asymmetric aminolysis of epoxides: Application for the synthesis of an enantiopure oxazolidine ring. New Journal of Chemistry, 42, 15325-15331. DOI: 10.1039/c8nj02960a

[12] Sun, L.B., Huang, Z.F., Reddu, V., Su, T., Fisher, A.C., Wang, X. (2020). A planar, conjugated N4-macrocyclic cobalt complex for heterogeneous electrocatalytic $\mathrm{CO}_{2}$ reduction with high activity. Angewandte Chemie, 132, 17252-17257. DOI: 10.1002/anie.202007445

[13] Rajak, S., Schott, O., Kaur, P., Maris, T., Hanan, G.S., Duong, A. (2020). Design of a [FeFe] macrocyclic metallotecton for lightdriven hydrogen evolution reaction. International Journal of Hydrogen Energy, 45, 26992708. DOI: 10.1016/j.ijhydene.2019.11.141

[14] Pablo, G.B., Dooshaye, M., Marcos, G.S., Primavera, P., Carolina, G.S., Jordi, B.B., Antoni, L. (2020). Redox metal-ligand cooperativity enables robust and efficient water oxidation catalysis at neutral $\mathrm{pH}$ with macrocyclic copper complexes. Journal of the American Chemical Society, 142, 17434-17446. DOI: 10.1021/jacs.0c06515

[15] Li, Y., Zou, X.Z., Qiu, W.D. (2018). Design and synthesis of porous 3D MOFs hybrid functional materials encapsulating macrocyclic metal complexes. Inorganic Chemistry Communications, $94, \quad 114-118$. D O I : 10.1016/j.inoche.2018.06.012

[16] Anna Benedict, B. (2019). Synthesis and spectral characterization of macrocyclic lanthanide(III) complexes of an 18-membered tetraaza tetraimine Schiff bases. Main Group Chemistry, 18, 1-13.

[17] Ragupathi, C., Vijaya, J.J., Narayanan, S. (2015). Highly selective oxidation of benzyl alcohol to benzaldehyde with hydrogen peroxide by cobalt aluminate catalysis: A comparison of conventional and microwave methods. $\mathrm{Ce}$ ramics International, 41, 2069-2080. DOI: 10.1016/j.ceramint.2014.10.002

[18] Diniz, J., Nunes, C.D., Monteiro O.C. (2020). Novel approach to synthesise $\mathrm{MoO}_{3}-\mathrm{TiO}_{2}$ nanocomposites for the photo-assisted oxidation of benzyl alcohol to benzaldehyde. Inorganic Chemistry Communications, 119, 108099. DOI: 10.1016/j.inoche.2020.108099

[19] Farrag, M., Yahya, R. (2020). Selective solar photocatalytic oxidation of benzyl alcohol to benzaldehyde over monodispersed $\mathrm{Cu}$ nanoclusters $/ \mathrm{TiO}_{2} /$ activated carbon nanocomposite. Journal of Photochemistry and Photobiology A: Chemistry, 396, 112527. DOI: 10.1016/j.jphotochem.2020.112527
[20] Si, J.Y., Liu, Y., Chang, S.Z., Wu, D., Tian, B.Z., Zhang, J.L. (2017). AgBr@TiO/GO ternary composites with enhanced photocatalytic activity for oxidation of benzyl alcohol to benzaldehyde. Research on Chemical Intermediates, 43, 2067-2080. DOI: 10.1007/s11164016-2747-9

[21] Christianah, A.A., Dimakatso, J.M., Ndzondelelo, B., Reinout, M. (2021). Highly tunable selectivity to benzaldehyde over $\mathrm{Pd} / \mathrm{ZrO}_{2}$ catalysts in Oppenauer oxidation of benzyl alcohol using acetone as $\mathrm{H}$-acceptor. Applied $\mathrm{Ca}$ talysis A: General, 613, 118022. DOI: 10.1016/j.apcata.2021.118022

[22] Liu, L.L., Tai, X.S., Zhou, X.J., Hou, J.X., Zhang, Z.H. (2019). Bimetallic AueNi alloy nanoparticles in a metaleorganic framework (MIL-101) as efficient heterogeneous catalysts for selective oxidation of benzyl alcohol into benzaldehyde. Journal of Alloys and Compounds, 790, 326-336. DOI: 10.1016/j.jallcom.2019.03.186

[23] Tai, X.S., Liu, L.L., Yin, J. (2014). Synthesis, crystal structure of tetra-nuclear macrocyclic $\mathrm{Cu}(\mathrm{II})$ complex material and its application as catalysts for $\mathrm{A}^{3}$ coupling reaction. Journal of Inorganic and Organometallic Polymers and Materials, 24, 1014-1020. DOI: 10.1007/s10904-014-0077-1

[24] Tai, X.S., Wang, X., Li, P.F. (2017). Synthesis, crystal structure, and luminescent property of a $\mathrm{Cd}(\mathrm{II})$ coordination polymer with a $\mathrm{N}$ nicotinoylglycine ligand. Crystals, 7, 33. DOI: 10.3390/cryst7020033

[25] Tai, X.S., Li, P.F., Liu, L.L. (2018). Synthesis, crystal structure and catalytic activity of a calcuim(II) complex with 4-formylbenzene1,3-disulfonate-isonicotinic acid hydrazone. Bulletin of Chemical Reaction Engineering \& Catalysis, 13, 429-435. DOI: 10.9767/bcrec.13.3.1961.429-435

[26] Wang, L.H., Wang, X., Tai, X.S. (2017). Synthesis, Crystal Structure and Catalytic Activity of a 1D Chained Ca(II) Coordination Polymer with 3,5-Bis(4-pyridylmethoxy)benzoate Ligand. Crystals, 7, 72. DOI: 10.3390/cryst7030072

[27] Tai, X.S., Jiang, J,H. (2012). Synthesis, crystal structure and luminescent property of Cd(II) complex with $N$-benzenesulphonyl- $L$ leucine. Materials, 5, 1626-1634. DOI: 10.3390/ma5091626

[28] Tai, X.S., Wang, X. (2017). Synthesis, structural characterization and antitumor activity of a $\mathrm{Ca}(\mathrm{II})$ coordination polymer based on 4 formyl-1,3-benzenedisulfonate-2-furoic acid hydrazide ligands. Crystallography Reports, $62, \quad 242-245$. $\quad$ D O I : $10.1134 / \mathrm{S} 1063774517020286$ 
[29] Sheldrick, G.M. (2015). Crystal structure refinement with SHELXL. Acta Crystallograph$i c a, \quad$ C $71, \quad 3-8$. D O I : $10.1107 / \mathrm{S} 2053229614024218$

[30] Dolomanov, O.V., Bourhis, L.J., Gildea, R.J., Howard, J.A.K., Puschmann, H. (2009). OLEX2: A complete structure solution, refinement and analysis program. Journal of Applied Crystallography, 42, 339-341. DOI: 10.1107/S0021889808042726

[31] Yin, J., Zhang, F.J., Tai, X.S. (2021). The crystal structure of trans-tetraaqua-bis(4acetylphenoxyacetato- $\mathrm{K}^{1} O$ ) manganese(II), $\mathrm{C}_{20} \mathrm{H}_{26} \mathrm{O}_{12} \mathrm{Mn}$. Zeitschrift für Kristallographie. New Crystal Structures, 236, 45-46. DOI: 10.1515/ncrs-2020-0467

[32] Tai, X.S., Zhou X.J., Liu, L.L., Cao, S.H., Wang, L.H. (2020). The crystal structure of c a t e n a - p o ly [ ( $\mu_{2}-2$ - ( ( 3 - b r o m o - 2 oxidobenzylidene)amino)acetato- $\left.\mathrm{k}_{4} O, N, O^{\prime}: O^{\prime}\right)$ (dimethylformamide-k ${ }_{1} O$ )] zinc(II), $\mathrm{C}_{12} \mathrm{H}_{13} \mathrm{~N}_{2} \mathrm{O}_{4} \mathrm{BrZn}$. Zeitschrift für Kristallographie. New Crystal Structures, 235, 901-902. DOI: 10.1515/ncrs-2020-0090
[33] Wang, L.H., Liang, L., Tai, X.S. (2020). The crystal structure 2,2'-bipyridine- ${ }^{2} N, N^{\prime}-(2-(3-$ amino-4-chlorobenzoyl)benzoato- $\left.\mathrm{k}^{1} \mathrm{O}\right)-(2-(3-$ a mino-4-chlorobenzoyl)benzoato$\left.\mathrm{k}^{2} O, O^{\prime}\right)$ zinc( I I) - et hanol (1/1), $\mathrm{C}_{40} \mathrm{H}_{3}{ }_{2} \mathrm{Cl}_{2} \mathrm{~N}_{4} \mathrm{O}_{7} \mathrm{Zn}$. Zeitschrift für Kristallographie. New Crystal Structures, 235, 1281-1283. DOI: 10.1515/ncrs-2020-0261

[34] Nabae, Y., Mikuni, M., Takusari, N., Hayakawa, T., Masa-aki Kakimoto, M. (2017). Aerobic oxidation of benzyl alcohol over TEMPOfunctionalized polyimide as a heterogeneous catalyst. High Performance Polymers, 29, 646-650. DOI: 10.1177/0954008317696565

[35] Li, Y., Sun, B., Yang, W. (2016). Synthesis of conjugated Mn porphyrin polymers with $\mathrm{p}$ phenylenediamine building blocks and effificient aerobic catalytic oxidation of alcohols. Applied Catalysis A: General, 515, 164-169. DOI: 10.1016/j.apcata.2016.02.003

[36] Asgharnejad, L., Abbasi, A., Najafifi, M., Janczak, J. (2019). One-, two- and threedimensional coordination polymers based on copper paddle-wheel SBUs as selective catalysts for benzyl alcohol oxidation. Journal of Solid State Chemistry, 277, 187-194. DOI: 10.1016/j.jssc.2019.06.011 